\title{
SELF AND MOBILE CHECK-IN ARE PLAYING IMPORTANT ROLE IN INCREASING CUSTOMER SATISFACTION
}

\author{
Mega Anindya Putri ${ }^{1}$, Arzinta Firdha Harisha ${ }^{2}$, Sekar Widyastuti ${ }^{3}$ \\ 1. STMT Trisakti, 2. STMT Trisakti, 3. STMT Trisakti \\ $\triangle$ corresponding author: arzintanya24@gmail.com
}

\begin{abstract}
Self and mobile check-in are widely known and implemented in air transportation all over the world. If self and mobile check-in were implemented well, it will give impact on short waiting time and easiness for passengers. This paper analyze how important self and mobile check-in for improving customer satisfaction in domestic airlines. As we know that it takes a time to queue in checkin counter. It will wasting time for passengers. This paper is using descriptive quantitative approach with Cartesius Diagram Analysis. According to Cartesius data, found that customer more satisfied with self and mobile check-in compared to the normal one. The sample being used is random sample. Based on the result, self and mobile check-in could improve customer satisfaction.
\end{abstract}

Keywords: self check-in; mobile check-in; customer satisfaction; waiting time; queue

\section{Introduction}

Check-in process is usually done by passenger when they arriving at an airport. Passengers requires check in by certain times prior to the departure of a flight. This duration approximately from fifth teen minutes to four hours. Check-in process is important procedure for passengers. At this step, ground staff need to validate the data between system and passenger identity card (document checking), baggage registration (hand over baggage), and seating registration (seat reference). Based on our observation, duration for check-in process from fifty minutes to two hours during peak hour. Lately, incident about long queue in check-in counter that makes the passenger, Abdul, missed their flight. It happened on Monday $5^{\text {th }}$ May 2017 at 15.50 during peak hour (Elvan Dany Sutrisno, 2017). He claimed that he have been waiting for 50 minutes in check-in counter. Abdul already been in airport 1 hour before his flight but because the long queue from security check-in that slowed him. Even though, based on act. 22 about check -in "The limits for check-in queue duration as referred in article $13 \mathrm{i}$ the longest time for every passenger is 20 minutes". Those 
incident are against act.22. Why this incidents can happened? Because amount of check- in counter not proportional with the number of passenger. Although, some of airlines in Indonesia have been provided self check-in machine and mobile check-in to make the process more effective and efficient.

(Drennen, 2011) stated that front liner will be replaced with Self Service Technology (SST) service that involved technology to provide selfsufficient service to customers. The average kiosk check-in only spend 2.5 minutes compared to normal check-in counter spend 3.5 minutes. Through Drenen conclusion SST influences both sides, airlines and the customer experience. SST play important role through easiness for both of airlines and customer, increasing maintenance delivery service, minimize operating cost and flexibility (service hours and location).

When we talking about waiting-time, it was the worse scenario for passengers caused of wasting their time and energy. It will create dissatisfaction and complain from customers SST have already been introduced in several literature as a alternative way to cut off the waiting times and intensify customer satisfaction. When SST is applied to reduced cost, it has big impact on waiting times and service level. For the particular system studied, when customer demand is very high, the use of an SSK (Self Service Kiosk) with a fast processing time will lead to short waitingtimes and greater service levels than the equivalent of three employee setup. The study finding further SST implementation will affect to lower waiting times (Kokkinou \& Cranage, 2013).

The customer is one of important aspects in business because the customer is the one who determine business growing rapidly or weaken in the future. Customer also the main contributor to profit in the company (Nurlita et al., 2016). Customer satisfaction is the main foundation in hospitality and tourism sector. Customer satisfaction coming from experiences after buying product or using service which match with their expectation. (Bogicevic, Bujisic, Bilgihan, Yang, \& Cobanoglu, 2016) findings using Robust analysis and conducted meditation analysis. Elaborate 
about the effect of SST to travelers satisfaction. The standardized of indirect effect between SSTs and customer satisfaction was statistically significant with a value of $0.144(\mathrm{p}<0.001)$. SSTs provide confidence to travelers and reduce their stress while traveling. The airports also should tenders various of SSTs that facilitate travelers' stay at the airport and provide a feeling of comfort and security. The sophisticated application technology will be major contributor with customer satisfaction in overall.

\section{Method}

The methodology using descriptive quantitative approach with Cartesius Diagram Analysis. Descriptive quantitative aims to explain a phenomenon by using numbers to base individual our group characteristics. The objective of this paper to elaborate the impact self and mobile check-in in enhancing customer satisfaction. Cartesius diagram analysis is the tool for this paper. By using that we explained the average expectation score and average performance score as an objective limit. X-variable is self and mobile check-in performance and $\mathrm{Y}$-variable is customer satisfaction for self and mobile check-in. This paper explain how X-variable influence Yvariable. We collect population from the people who have been use airline and for sample from some people who have been use airline too and know about self and mobile check-in. A questionnaire was then designed to know about passengers opinion about self and mobile check-in process more effective than the traditional one. It contains five variables such as tangible, reliability, assurance, empathy and responsiveness (Sastranegara, 2016). The measurement items are adapted for self and mobile check-in performance (x) and self and mobile check-in, customer satisfaction (y) are based on a 5-point Likert scale related from $1=$ strongly disagree/unimportant to $5=$ strongly agree/important (Marty, 2016). It took 150 respondent include 84 women $(56 \%)$ and 66 men (44\%). 


\section{Discussion and Result}

\section{Self and mobile check-in reduce waiting time}

Waiting-time is forecasting tools to identifying both quality services and customer satisfaction. Evidence found that there are relationships between actual waiting-time, perceived waiting-time, perceived service quality and customer satisfaction. However, the strong influence for customer satisfaction and perceived service quality is actual waiting-times (Kokkinou \& Cranage, 2013). Based on our observation at Soekarno-Hatta Int'1 Airport T2 on Saturday $4^{\text {th }}$ Nov 2017, it found that during peak hours the average of waiting times in check-in counter can exceed 1 hours. Based on our reservation data, the longest queueing time is two hours and usually there are at least 20 persons in queue line.

According to our observation data, check-in counter overwhelmed with amount of passengers. Also, the number of check-in counter not proportional with passengers. This will influence performance of check-in counter not optimum. Therefore, service operator have to be focus their attention on reducing actual waiting times in order to improve customer satisfaction, perceived service quality and service operators (Kokkinou \& Cranage, 2013; Pengguna et al., 2016)

Nowadays almost all business uses the information technology (IT) which becomes one of the reliable media for communication and business. The development of telecommunication technology and computerization also causes cultural changes in the daily life (Simarmata, Rs, Keke, \& Panjaitan, 2016) Self and mobile check-in provide short waiting times and maybe no waiting times because we can access that through our devices everywhere and anytime. The whole process only spend 2 minutes in average. Based on table 3, passengers who have service combination no 1 (normal counter check-in) have the longest time (2.6 minutes) among the others because service combination no.1 only providing services in counter. Compared to service combination no.1, service combination no. 2 have shorter processing times (1.6 minutes). It has 1 minutes range because it serve passengers not only in counter but also via online. For service 
combination no. 3 passengers spend 2.1 minutes with the facilities of counter and kiosk. However, service combination for no.4 only spend 1.1 minutes in overall with service provided by counter, kiosk, and online. From those data, proven that self and mobile check-in could shorten waiting times and make check-in process faster that usual.

Table.1

Combination of services provided by different check-in facilities

\begin{tabular}{|c|c|c|c|c|c|c|c|}
\hline \multirow{2}{*}{$\begin{array}{l}\text { Type of } \\
\text { services }\end{array}$} & \multicolumn{7}{|c|}{ Combination of services } \\
\hline & 1 & 2 & 3 & 4 & 5 & 6 & 7 \\
\hline $\begin{array}{c}\text { Ticket } \\
\text { purchasing }\end{array}$ & $\checkmark$ & $\checkmark$ & & & & & \\
\hline Check-in & $\checkmark$ & $\checkmark$ & $\checkmark$ & $\checkmark$ & & & \\
\hline Boarding pass & $\checkmark$ & $\checkmark$ & $\checkmark$ & $\checkmark$ & $\checkmark$ & $\checkmark$ & \\
\hline $\begin{array}{c}\text { Checking } \\
\text { baggage }\end{array}$ & $\checkmark$ & & $\checkmark$ & & $\checkmark$ & & $\sqrt{ }$ \\
\hline $\begin{array}{l}\text { Type of } \\
\text { facilities }\end{array}$ & & & & & & & \\
\hline Counter & $\checkmark$ & $\checkmark$ & $\checkmark$ & $\checkmark$ & $\checkmark$ & $\checkmark$ & $\checkmark$ \\
\hline Kiosk & & & $\checkmark$ & $\sqrt{ }$ & $\sqrt{ }$ & $\checkmark$ & $\sqrt{ }$ \\
\hline Online & & $\checkmark$ & & $\sqrt{ }$ & & $\sqrt{ }$ & \\
\hline Barcode & & & & & & $\checkmark$ & \\
\hline
\end{tabular}

Source : (Hsu, Chao, \& Shih, 2012)

Table.2

Distribution of arrival time for check-in and services required by departing passengers

\begin{tabular}{|c|c|c|c|c|c|c|c|}
\hline No & $\begin{array}{c}\text { Time to } \\
\text { take off }\end{array}$ & $\begin{array}{c}\text { Number } \\
\text { of } \\
\text { passengers }\end{array}$ & $\begin{array}{c}\text { Percentage } \\
(\%)\end{array}$ & $\begin{array}{c}\text { Service } \\
\text { combination }\end{array}$ & $\begin{array}{c}\text { Processing } \\
\text { time (min) }\end{array}$ & $\begin{array}{c}\text { Number } \\
\text { of } \\
\text { passengers }\end{array}$ & $\begin{array}{c}\text { Percentage } \\
(\%)\end{array}$ \\
\hline 1 & $2,5-3,0 \mathrm{~h}$ & 56 & 28.4 & 1 & 2.6 & 6 & 3.0 \\
\hline 2 & $2,0-2,5 \mathrm{~h}$ & 82 & 41.7 & 2 & 1.6 & 0 & 0.0 \\
\hline 3 & $1,5-2,0 \mathrm{~h}$ & 45 & 22.8 & 3 & 2.1 & 157 & 79.7 \\
\hline 4 & $1,0-1,5 \mathrm{~h}$ & 10 & 5.1 & 4 & 1.1 & 6 & 3.0 \\
\hline 5 & $<1 \mathrm{~h}$ & 4 & 2.0 & 5 & 1.5 & 23 & 11.7 \\
\hline 6 & & & & 6 & 0.5 & 2 & 1.0 \\
\hline 7 & & & & 7 & 1.0 & 3 & 1.5 \\
\hline
\end{tabular}

Source : (Hsu et al., 2012)

Indonesian domestic airlines should consider to using self and mobile check-in to mitigate long queue during peak hours. Airlines don't need to replace all counters with SST but they should arrange the strategy about 
combination services between normal counter and self and mobile check-in. Traditional check-in counter will certainly remain for several reasons, such as security, logistical baggage aspects and traveler preference for personal treatment and ease of use, especially on international flights (Bruno \& Genovese, 2010). Although, self and mobile check-in promoted conveniences and faster process, but the things it still machine which ordered by human. It can't make decisions and solve several problems. Furthermore, dynamic allocation of check-in facilities is also more efficient than fixed allocation in achieving shorter waiting times and better utilization in sufficing services to passengers (Hsu, Chao, \& Shih, 2012).

\section{Self and mobile check-in enhance customer satisfaction}

Based on our survey data, most of respondent more satisfied with self and mobile check-in than with normal check-in counter.

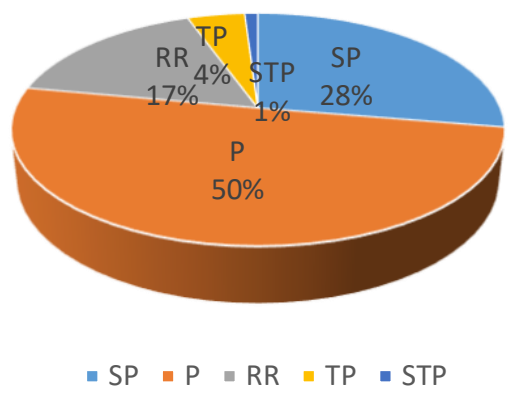

Figure 1.

Self and mobile check-in performance $(X)$

From graph.1 we get amount of passengers who choose SP(Sangat Penting / Very Important) is 42 people with presentation 28\%, $\mathrm{P}$ (Penting/Important) is 75 people with presentation 50\%, RR (Ragu-Ragu / draw full) is 25 people with presentation 17\%, TP (Tidak Penting/Not Important) is 6 people with presentation 4\%, STP (Sangat Tidak Penting/Very Not Important) is 2 people with presentation $1 \%$. 


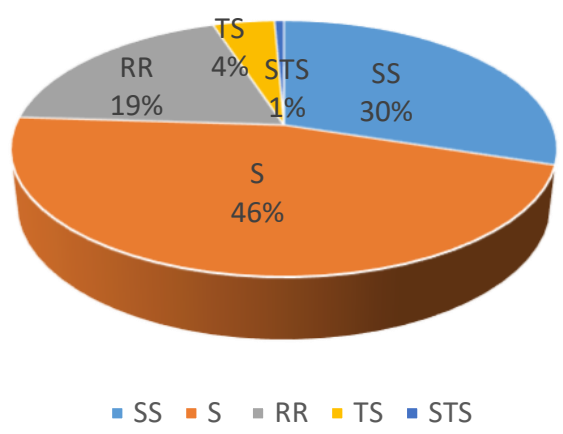

Figure 2.

Customer Satisfaction for self and mobile check-in (Y)

From graph.2 we get amount of passengers who choose SS(Sangat Setuju / Very Agree) is 45 people with presentation 30\%, S(Setuju/Agree) is 69 people with presentation $46 \%$, RR (Ragu-Ragu / draw full) is 28 people with presentation 19\%, TS (Tidak Setuju/Not Agree) is 6 people with presentation 4\%, STS (Sangat Tidak Setuju/Very Not Agree) is 2 people with presentation $1 \%$.

From both of graph, self and mobile check-in have been achieve good rating in passengers opinion. From level of compatibility indicator (TKI) we calculate and got the result with formula :

$\mathrm{TKI}=\frac{x}{y} x 100 \%=\frac{3,98}{4,01} \mathrm{x} 100 \%=99,2 \%$

There are 5 indicators which under level of compatibility and 5 indicators that above level of compatibility. TKI points got from calculation with formula:

$\mathrm{TKI}=\frac{\text { performance }(x)}{\text { satisfaction }(y)}=\frac{3,98}{4.01}=0,992$

The result of TKI calculation is 0,992 . Based on scale interpretation measurement by J. Supranto, this points existed in very satisfaction level which approximate between 0,81 to 1,00 points. So according to TKI indicator, in overall customers feel very satisfied with self and mobile check-in that have been provided by airlines. 


\begin{tabular}{|l|l|}
\hline Interval & Interpretation \\
\hline $0,00-0,199$ & Unsatisfied \\
\hline $0,20-0,399$ & Less Satisfied \\
\hline $0,40-0,599$ & Enough Satisfied \\
\hline $0,60-0,799$ & Statisfied \\
\hline $0,81-1,00$ & Very Satisfied \\
\hline
\end{tabular}

Source: J. Supranto

To be able to assess the position data that has been analyzed, it required a Cartesius diagram which will describe the average expectation score and average performance score as an objective limit.

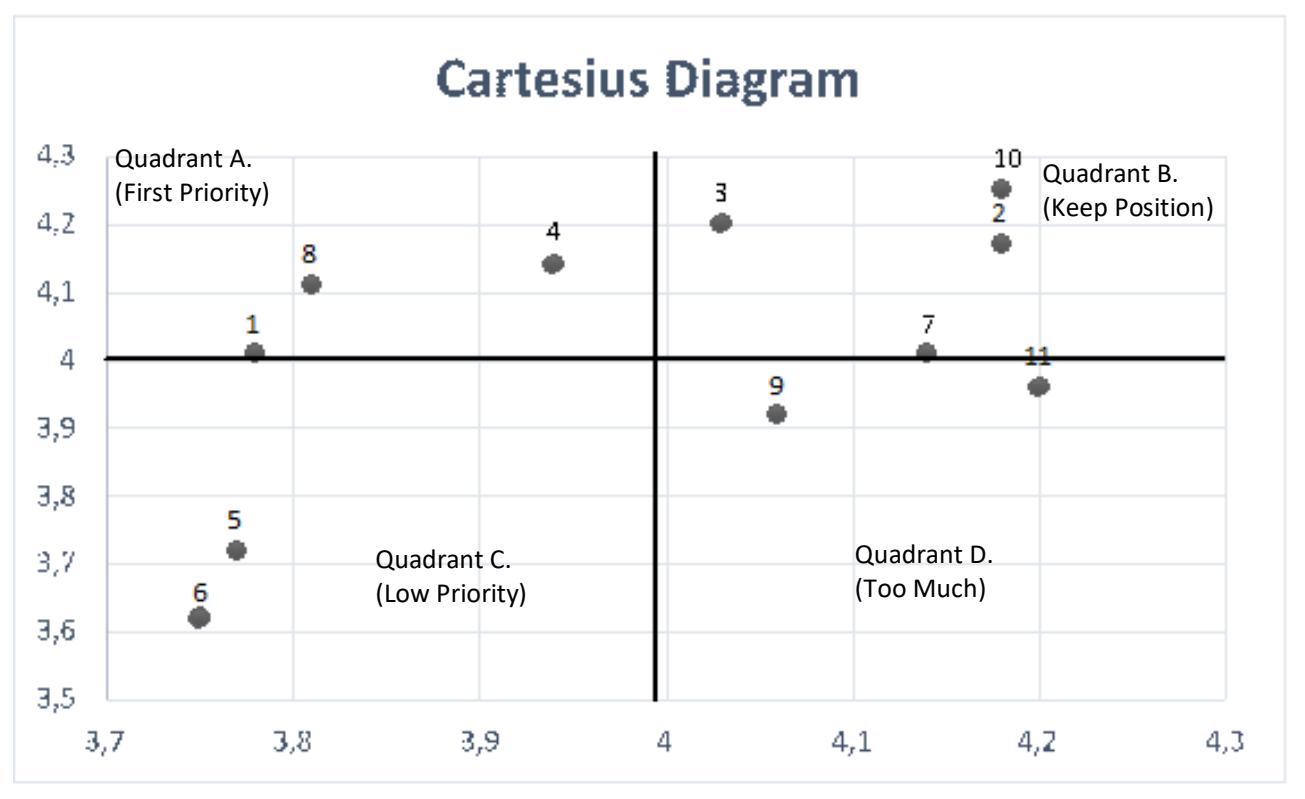

Figure 3.

\section{Cartesius Diagram}

From the graph above, it include of four part and each part can describe like this:

Quadrant A. is about first priority which passengers have been satisfy about service from self and mobile check-in. It is the good position from another quadrant because it can say the top condition of situation. The 
factors in this quadrant is effectiveness and efficiency of self and mobile check-in; accurate of the data in self and mobile check-in; and physics condition of self and mobile check-in.

Quadrant B. is about keep position which not good and not bad for the position. It is the normal and stable position for the situation. Between self and mobile check-in performance and customer satisfaction is in the same position. The factors in this quadrant is benefit of self and mobile check-in make more faster for check-in; self and mobile check-in is the best solution for reduce queue line; operate system of self and mobile check-in is 24 hours; and also handling of self and mobile check-in more faster than counter check-in

Quadrant C. is about the low position and priority. This situation must do correction and improving for back up quality. We can't let it left behind from another aspect. The factors in this quadrant is promotion of information about self; and mobile check-in and guide for use self and mobile check-in.

Quadrant D. is about out of capacity. The factors in this quadrant is self and mobile check-in more attract passengers to use this way to take check-in time; and self and mobile check-in keep all data of passengers accurately.

\section{Conclusion}

This study has elaborated how self and mobile check-in could improve customer satisfaction. The paper represent how self and mobile check-in to enhancing customer satisfaction through its short waiting times, fast process and convenience. According cartesius diagram analyst found that overall customer more satisfied with self and mobile check-in compared with normal check-in counter.

Quadrant A stated about service which become top priority and have been satisfy which are effectiveness and efficiency of self and mobile check-in; accurate of the data in self and mobile check-in; and physics condition of self and mobile check-in. Quadrant B is normal and stable 
position. Self and mobile check-in performance (x) and customer satisfaction in same level (y). The factors in this quadrant is benefit of self and mobile check-in make more faster for check-in; self and mobile checkin is the best solution for reduce queue line; operate system of self and mobile check-in is 24 hours; and also handling of self and mobile check-in more faster than counter check-in. For Quadrant C is the position which low position for customer and need to be improved. The services can't fulfill customer expectation. The factors in this quadrant is promotion of information about self; and mobile check-in and guide for use self and mobile check-in. Quadrant D out of capacity position which customer feel dissatisfied with services. The factors in this quadrant is self and mobile check-in more attract passengers to use this way to take check-in time; and self and mobile check-in keep all data of passengers accurately.

The percentage of customer satisfaction reach $99,2 \%$ and it categorized as top (very satisfied) indicator level. Thus, it's proven with our observation data that self and mobile check-in could increasing customer satisfaction.

\section{References}

Bogicevic, V., Bujisic, M., Bilgihan, A., Yang, W., \& Cobanoglu, C. (2016). The impact of traveler-focused airport technology on traveler satisfaction. Technological Forecasting and Social Change, (March), 0-1. https://doi.org/10.1016/j.techfore.2017.03.038

Bruno, G., \& Genovese, A. (2010). A mathematical model for the optimization of the airport check-in service problem. Electronic Notes in Discrete Mathematics, 36(C), 703-710. https://doi.org/10.1016/j.endm.2010.05.089

Drennen, H. (2011). Self Service Technology in Airports And the Customer Experience. Unlv, 1-37.

Elvan Dany Sutrisno. (2017). Bandara Halim Crowded, Banyak Penumpang Gagal Check In. Retrieved from https://news.detik.com/berita/3494562/bandara-halim-crowdedbanyak-penumpang-gagal-check-in

Hsu, C. I., Chao, C. C., \& Shih, K. Y. (2012). Dynamic allocation of checkin facilities and dynamic assignment of passengers at air terminals. Computers and Industrial Engineering, 63(2), 410-417. https://doi.org/10.1016/j.cie.2012.04.003

Kokkinou, A., \& Cranage, D. A. (2013). Using self-service technology to 
reduce customer waiting times. International Journal of Hospitality Management, $33(1)$,

435-445.

https://doi.org/10.1016/j.ijhm.2012.11.003

Marty, Y. (2016). Airline Customer Retention in Indonesia 2015. International Journal of Management Sciences and Business Research, 2015(2), 41-53.

Nurlita, L., Sekolah, S., Manajemen, T., Trisakti, T., Made, I., Sekolah, A., ... Trisakti, M. T. (2016). Loyalitas Pelanggan Pada Perusahaan Freight Forwarding Customer Loyalty of Freight Forwarding Company, 3(3), 299-308.

Pengguna, K., Transportasi, J., Loyalitas, U. M., Saribanon, E., Tinggi, S., Trisakti, M. T., ... Trisakti, T. (2016). Kepuasan Pengguna Jasa Transportasi Untuk Meningkatkan Loyalitas the Satisfaction of Transportation'S Customers To Enchance Loyalty. Jurnal Manajemen Transportasi \& Logistik, 3(3), 317-326.

Sastranegara, B. H. (2016). Jasa Pelayanan Bandara Halim Perdana Kusuma dan, 3(1), 1-11.

Simarmata, J., Rs, M., Keke, Y., \& Panjaitan, F. (2016). the Airline Customer'S Buying Decision Through Online Travel Agent: a Case Study of the Passengers of Scheduled Domestic Airlines in Indonesia. International Journal of Economics, Commerce and Management United Kingdom, 3(3), 335-349. Retrieved from http://ijecm.co.uk/ 